\title{
Management of lipids in adults with diabetes mellitus and nephropathy and/or chronic kidney disease: summary of joint guidance from the Association of British Clinical Diabetologists (ABCD) and the Renal Association (RA)
}

\author{
PATRICK B MARK, ${ }^{1}$ PETER WINOCOUR, ${ }^{2}$ CAROLINE DAY ${ }^{3}$
}

\begin{abstract}
In diabetes, nephropathy and chronic kidney disease are independent and co-existent harbingers of end stage renal failure as well as increased morbidity and premature mortality due to cardiovascular disease. Whilst lipid management is beneficial in reducing cardiovascular risk in populations with and without diabetes, there is a paucity of national guidance on the utility of this approach in diabetes patients with renal disease. This joint guidance collates the best available evidence and expert opinion (in the absence of clear evidence) to provide 28 guidelines to empower clinicians to deliver optimal lipid management according to renal status in these patients at high cardiovascular risk. The abridged guideline herein provides a practical overview of the full document. The full guidance with detailed rationale is available online. Br J Diabetes 2017:17:64-72
\end{abstract}

Key words: diabetes, nephropathy, chronic kidney disease, cardiovascular disease, lipids, statins, guidelines

\section{Introduction}

Cardiovascular disease is a key contributor to excess morbidity and premature mortality in diabetes and chronic kidney disease is an independent and major risk factor for cardiovascular disease. Lipids are a modifiable risk factor and good lipid management offers improved outcomes for diabetic patients with concomitant renal disease.

The primary purpose of these guidelines is to provide practical

Queen Elizabeth University Hospital, Glasgow, UK Queen Elizabeth II Hospital, Welwyn Garden City, UK

Aston University, Birmingham, UK

Address for correspondence: Dr Paddy B Mark Glasgow Renal and Transplant Unit, Queen Elizabeth University Hospital, 1345 Govan Road, Glasgow, G51 4TF, UK

Telephone: +44 (0)1412011100

E-mail: Patrick.mark@glasgow.ac.uk

http://dx.doi.org/10.15277/bjd.2017.125
Box 1 Differentiating renal disease in diabetes

Nephropathy (DN)

Damage to glomerular capillaries in patients with diabetes mellitus resulting in albuminuria in the absence of other causes of albuminuria

Diabetes mellitus chronic kidney disease (DM CKD)

Presence of structural or functional renal abnormalities, present for $>3$ months in patients with diabetes mellitus

recommendations for UK diabetologists, nephrologists, general practitioners and other members of the multidisciplinary team involved in the care of adults with diabetes who also have nephropathy (DN) and/or chronic kidney disease (DM CKD) (Box 1).

The abridged guidelines herein provide a practical overview of the full document which should be consulted when designing treatment strategies. The full guidelines are available online. ${ }^{*}$ The full guidance can also be accessed via the $A B C D$ and Renal Association websites.

The presence and extent of renal disease is generally defined by measurement of serum creatinine from which an estimated glomerular filtration rate (eGFR) is generated, and a urinary albumin:creatinine ratio test - the latter being more sensitive for detection of diabetic nephropathy (Figure 1).

\section{Methodology}

These clinical practice guidelines are based upon systematic literature searches conducted between October 2013 and March 2016. We searched Pubmed/MEDLINE (search terms used were 'diabetes' AND 'nephropathy/chronic kidney disease/nephropathy'), the Cochrane database of systematic reviews and hand searched reference lists and articles identified by the writing group members

* Mark PB, Winocour P. ABCD-Renal Association Clinical Practice Guidelines for management of lipids in adults with diabetes mellitus and nephropathy and/or chronic kidney disease. 2017. www. diabetologistsabcd.org.uk and www.renal.org 
Figure 1. Glomerular filtration rates (GFR) and albumin:creatinine ratio categories and risk of adverse outcomes

\begin{tabular}{|c|c|c|c|c|}
\hline \multirow{3}{*}{$\begin{array}{l}\text { eGFR } \\
(\mathrm{ml} / \mathrm{min} / \\
\left.173 \mathrm{~m}^{2}\right) \\
\end{array}$} & \multicolumn{3}{|c|}{ Urinary albumin:creatinine ratio } & \multirow{3}{*}{$\begin{array}{l}\text { CKD grade } \\
\text { Previously CKD } \\
\text { stage } 1-5\end{array}$} \\
\hline & $<3 \mathrm{mg} / \mathrm{mmol}$ & $3-29 \mathrm{mg} / \mathrm{mmol}$ & $\geq 30 \mathrm{mg} / \mathrm{mmol}$ & \\
\hline & $<30 \mathrm{mg} / \mathrm{g}$ & $30-299 \mathrm{mg} / \mathrm{g}$ & $\geq 300 \mathrm{mg} / \mathrm{g}$ & \\
\hline$>90$ & \multirow{2}{*}{$\begin{array}{l}\text { No CKD } \\
\text { in the } \\
\text { absence } \\
\text { of markers } \\
\text { of kidney } \\
\text { damage }\end{array}$} & & & $\begin{array}{c}\text { G1 } \\
\text { Normal } \\
\text { or high GFR }\end{array}$ \\
\hline $60-89$ & & & & $\begin{array}{c}\text { G2 } \\
\text { Slight } \\
\downarrow \text { in GFR }\end{array}$ \\
\hline $45-59$ & & & & $\begin{array}{c}\text { G3a } \\
\text { Mild-moderate } \\
\downarrow \text { in GFR }\end{array}$ \\
\hline $30-44$ & & & & $\begin{array}{c}\text { G3b } \\
\text { Moderate-severe } \\
\downarrow \text { in GFR }\end{array}$ \\
\hline $15-29$ & & & & $\begin{array}{c}\text { G4 } \\
\text { Severe } \\
\downarrow \text { in GFR }\end{array}$ \\
\hline \multirow[t]{2}{*}{$<15$} & & & & $\begin{array}{c}\text { G5 } \\
\text { Renal failure }\end{array}$ \\
\hline & $\begin{array}{c}\text { A1 } \\
\text { Normal } \\
\text { or slight }\end{array}$ & $\begin{array}{c}\text { A2 } \\
\text { Micro- } \\
\text { albuminuria }\end{array}$ & \begin{tabular}{|c|}
$\mathrm{A} 3$ \\
Macro- \\
albuminuria
\end{tabular} & \\
\hline
\end{tabular}

Based on Renal Association http://www.renal.org/information-resources/the-uk-eckdguide/about-egfr\#sthash.mQ76je8d.dpbs and KDIGO 2012 http://www.kdigo.org/clinical_practice_guidelines/pdf/CKD/KDIGO_2012_CKD_GL.pdf

up to March 2016. We also reviewed all related guidelines from the National Institute for Clinical Excellence, the Renal Association, Kidney Disease Improving Global Outcomes (KDIGO), the European Renal Association Best Practice Guidelines and the American and European Diabetes Associations.

This grading system classifies expert recommendations as 'strong' (Grade 1) or 'weak' (Grade 2) and the quality or level of evidence is designated as high (Grade A) to very low (D). ${ }^{1,2}$ (See full guidance online).*

\section{Guideline summary}

The evidence grading has determined the strength of recommendations (ranging from 1A to 2D), suggested standards for clinical audit and the outstanding questions for future research.

The guidelines are listed here with diagrams to summarise their utility in type 1 diabetes (Figure 2) and type 2 diabetes (Figure 3) and suggested audit measures are noted. It is recommended that the unabridged guidance is viewed online.*

\section{Guidelines}

A detailed rationale for these guidelines can be viewed online.*

To support rapid access to evidence from this abbreviated publication, the references used to inform these guidelines (Box 2) are listed at the end of this document.

The following standard lipid abbreviations are used in these
Box 2 Listing of references used to support the guidelines

\begin{tabular}{ll}
\hline Guidelines & References \\
$1-7$ & $4,8,9,11,15,17-42$ \\
8 & $5,9,11-13,15,21,22,24,25,29,31,35-37,41,43-49$ \\
$9-13$ & $3,4,6,7,9,10,14,16,22,23,27,28,30,32,33,49-73$ \\
$14-21$ & $58,65,74-90$ \\
$22-24$ & $23,55,58,65-67,70,72,76,91-95$ \\
$25-28$ & $4,23,58,61,63,94-119$
\end{tabular}

guidelines: total cholesterol (TC), high density lipoprotein (HDL), low density lipoprotein (LDL) and triglycerides (TG).

\section{Guideline 1}

We recommend that evaluation of a full lipid profile (TC, LDL cholesterol, HDL cholesterol, TGs) is performed in patients with DN-DM CKD as is current practice. (Grade 1A)

\section{Guideline 2}

We suggest that the lipid profile is assessed at least annually in patients with DN-DM CKD. (Grade 1C)

\section{Guideline 3}

We advise that the major goal of commencing lipid-lowering therapy in adult patients with DN-DM CKD is to reduce risk of cardiovascular events. (Grade 2A)

We suggest that, in patients with stage 1-2 DN-DM CKD, lipidlowering therapy with statins is commenced in the following categories:

- Patients with type 1 diabetes and persistent microalbuminuria aged $>30$ years

- Patients with type 2 diabetes with progressing early CKD (loss of GFR $>5 \mathrm{ml} / \mathrm{min} /$ year) irrespective of albuminuria status

- Patients with type 2 diabetes aged $>40$ years irrespective of cholesterol levels

- All patients with type 2 diabetes and persistent microalbuminuria or macroalbuminuria

\section{Guideline 4}

We recommend that lipid-lowering therapy with statins should be considered for all patients with stage 3-5 DN-DM CKD. (Grade 1B)

\section{Guideline 5}

We recommend review of the lipid profile on commencement or change of modality of renal replacement therapy (dialysis or kidney transplantation). (Grade 1D)

\section{Guideline 6}

We suggest that in patients with end stage renal disease (ESRD), measurement of the lipid profile should be performed annually to assess compliance and need for continuing therapy. (Grade 2D)

\section{Guideline 7}

We recommend caution with lipid-lowering therapy in women of 
Figure 2. Lipid management in type 1 diabetes*

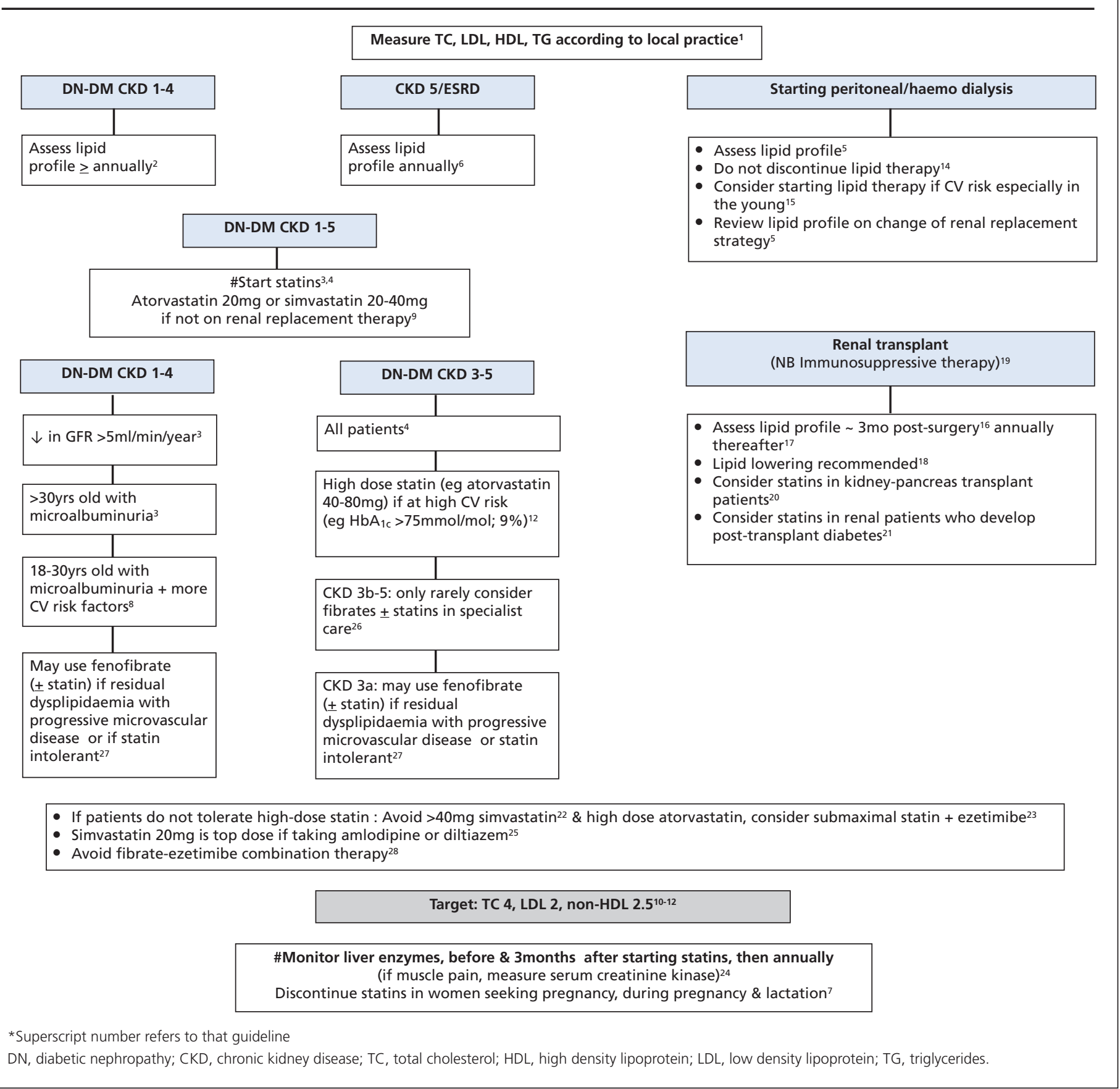

child-bearing potential and that these agents should be discontinued if pregnancy is contemplated. Lipid-lowering therapy should be discontinued during pregnancy and lactation. (Grade 1B)

\section{Guideline 8}

We suggest that in patients with type 1 diabetes with CKD stage $1-2$, lipid-lowering therapy with statins is commenced in patients aged 18-30 years with persistent albuminuria and additional CVD risk factors evident. (Grade 1B)

\section{Guideline 9}

We suggest that in DN-DM CKD patients not requiring renal replacement therapy, it is appropriate to initiate statin therapy with either atorvastatin $20 \mathrm{mg}$ or simvastatin 20-40 mg. (Grade 1D)

\section{Guideline 10}

We suggest that in patients with reduced GFR \pm persistent albuminuria the management of dyslipidaemia should be similar irrespective of whether the individual has type 1 or type 2 diabetes. (Grade 1B) 
Figure 3. Lipid management in type 2 diabetes*

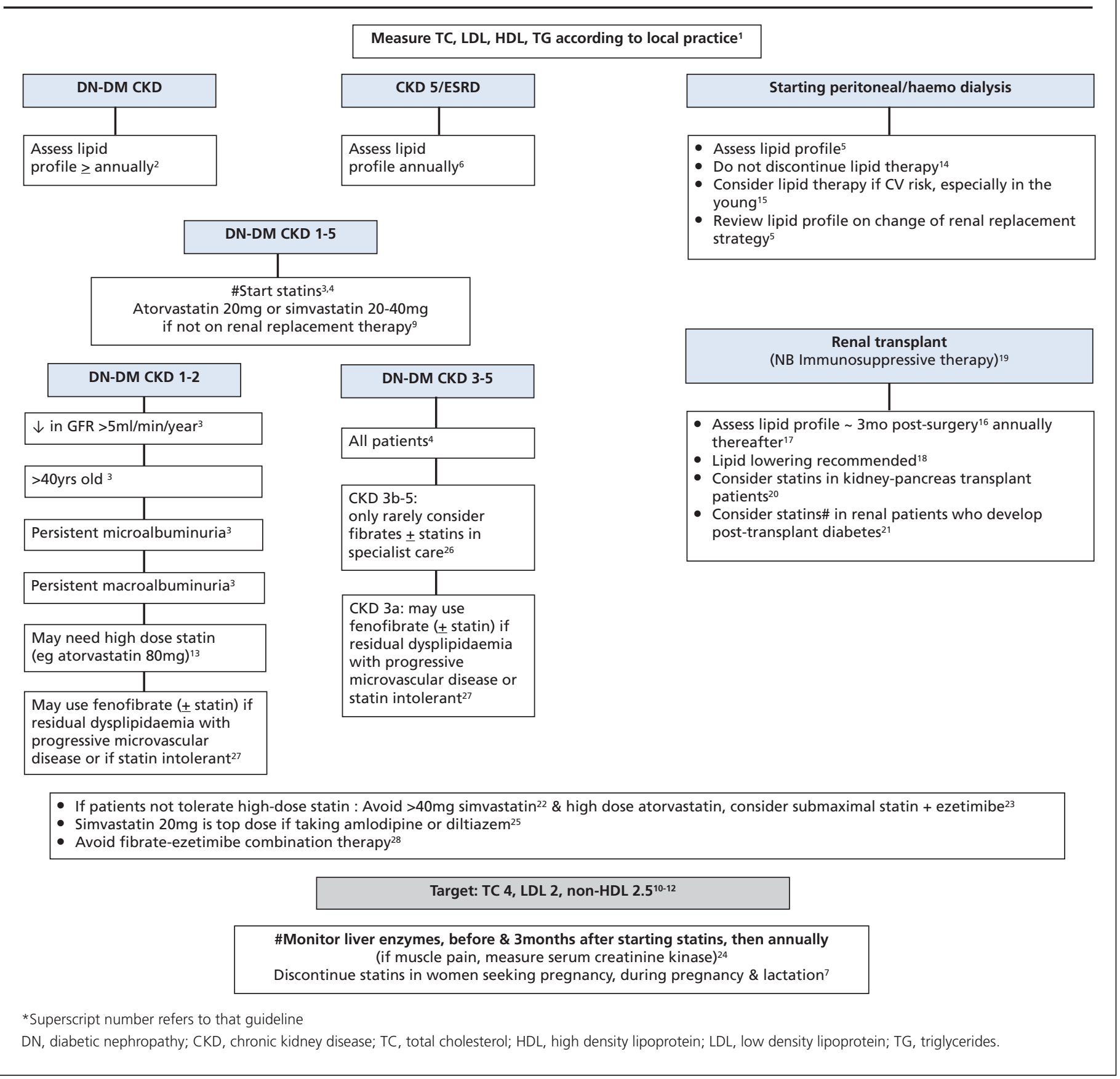

\section{Guideline 11}

We suggest that in patients with type 1 diabetes with persistent albuminuria and/or reduced eGFR (60-90), statin use should aim to reduce TC to $4.0 \mathrm{mmol} / \mathrm{l}$, LDL cholesterol to $2 \mathrm{mmol} / \mathrm{l}$ and non-HDL cholesterol to $2.5 \mathrm{mmol} / \mathrm{l}$. (Grade 1D)

\section{Guideline 12}

We suggest that higher intensity statin use (atorvastatin 40-80 mg) can be considered for those with persistent albuminuria and/or reduced eGFR (30-60) at highest CVD risk (e.g. aged >40 years; poor glycaemic control $\left(\mathrm{HbA}_{1 \mathrm{c}}>75 \mathrm{mmol} / \mathrm{mol}\right)$; additional CVD risk factors: smoking, hypertension, dyslipidaemia; proliferative retinopathy) who do not attain lipid targets in Guideline 11 on lower statin doses. (Grade 1D)

\section{Guideline 13}

We recommend that all type 2 diabetes patients with stage 1-2 CKD with albuminuria, who have the highest risk of CVD, should be considered for high intensity statins such as atorvastatin $80 \mathrm{mg}$. (Grade 1A) 


\section{Guideline 14}

We recommend that in patients with DN-DM CKD already treated with lipid-lowering therapy who commence dialysis, lipid-lowering therapy should be continued. (Grade 2C)

\section{Guideline 15}

We suggest that the decision to commence lipid-lowering therapy de novo in DN-DM CKD patients requiring either haemodialysis or peritoneal dialysis should take into account risk of future atherosclerotic vascular events, life expectancy on dialysis and other co-morbid disease. In the absence of compelling evidence, it seems that any benefits of statin therapy in dialysis patients are likely to be greatest in younger patients with a longer projected treatment period, with the probability of renal replacement therapy. (Grade 2C)

\section{Guideline 16}

We recommend that all patients with DN-DM CKD who have undergone renal transplantation should have lipid status assessed once the immediate postoperative period has passed (typically 3 months post-transplantation). (Grade 2C)

\section{Guideline 17}

We suggest that in renal transplant recipients with DN-DM CKD, lipid status is assessed annually. (Grade 2C)

\section{Guideline 18}

We recommend that lipid-lowering therapy should be commenced in patients with DN-DM CKD who have undergone renal transplantation. (Grade 1B)

\section{Guideline 19}

We suggest that in patients with DN-DM CKD who have undergone kidney transplantation or kidney-pancreas transplantation, the choice and dose of lipid-lowering therapy should take into account concurrent immunosuppressive therapy. (Grade 2D)

\section{Guideline 20}

We suggest that all patients with DN-DM CKD who have undergone kidney-pancreas transplantation should receive statin treatment. (Grade 2D)

\section{Guideline 21}

We suggest that all patients who develop post-transplant diabetes mellitus are treated with statins. (Grade 2D)

\section{Guideline 22}

We do not recommend $>40 \mathrm{mg} /$ day simvastatin in DN-DM CKD due to the increased risk of muscular side effects. (Grade 1A)

\section{Guideline 23}

We suggest submaximal statin (in patients who are unable to tolerate higher statin doses) and ezetimibe combination therapy should be considered as an alternative to high intensity atorvastatin in DNDM CKD at all stages. (Grade 1B)

\section{Guideline 24}

We recommend routine measurement of liver enzymes before statin initiation in DN-DM CKD and at 3 months after commencement and annually thereafter. Routine measurement of serum creatinine kinase is unnecessary in the absence of muscle pain (consistent with NICE guideline CG181). (Grade 1A)

\section{Guideline 25}

We recommend that when prescribed in combination with amlodipine or diltiazem, the maximum dose of simvastatin should not exceed $20 \mathrm{mg}$. (Grade 1B)

\section{Guideline 26}

We suggest that there is no role for fibrates in advanced DM CKD (3b-5) - either as monotherapy or in combination with statins outside specialist care. (Grade 1A)

\section{Guideline 27}

We suggest that fenofibrate therapy alone or alongside statins should only be used in DN-DM CKD 3a or earlier stages - primarily to reduce risks of progressive microvascular events in patients with statin intolerance or residual dyslipidaemia despite statin therapy. (Grade 2C)

\section{Guideline 28}

We do not recommend fibrate-ezetimibe combination therapy in DN-DM CKD, outwith specialist lipid clinic advice. (Grade 2D)

\section{Clinical audit}

Suggested audit measures for clinical practice guidelines for management of lipids in patients with DN-DM CKD (to assist data collection for audit a chart (Chart 1 ) is provided below. To enhance the utility of the audit for local circumstances this chart can be downloaded as a modifiable Excel document: Appendix 2 in reference*).

i. Proportion of DN-DM CKD patients not requiring dialysis taking statins for primary and secondary prevention of cardiovascular disease

ii. Level of achieved total cholesterol $(<5$ and $<4 \mathrm{mmol} / \mathrm{L})$, LDL cholesterol ( $<3$ and $<2 \mathrm{mmol} / \mathrm{L}$ ), non-HDL cholesterol $(<3$ and $<2.5 \mathrm{mmol} / \mathrm{L}$ ) in patients not requiring dialysis

iii. Proportion of DN-DM CKD on dialysis with measure of fasting lipids measured during first 6 months of commencement of dialysis

iv. Proportion of DN-DM CKD on dialysis taking statins for primary and secondary prevention of cardiovascular disease

v. Proportion of DN-DM CKD renal transplant patients with annual measure of fasting lipids

vi. Proportion of DN-DM CKD renal transplant patients taking statins for primary and secondary prevention of cardiovascular disease

vii. Attained levels of total cholesterol, LDL cholesterol, non-HDL cholesterol as stated previously

viii. Proportion of DN-DM CKD renal transplant patients achieving dyslipidaemia targets (see ii above) 
Chart 1. Data collection chart for audit of lipid management

\begin{tabular}{|c|c|c|c|}
\hline Diabetes patients with DN-DM CKD & T1DM & T2DM & Total \\
\hline \multicolumn{4}{|l|}{ Number of patients } \\
\hline \multicolumn{4}{|l|}{ Patients not requiring dialysis } \\
\hline \multicolumn{4}{|l|}{ Fasting lipids measured annually } \\
\hline \multicolumn{4}{|l|}{$\begin{array}{l}\text { Taking statins for primary or secondary } \\
\text { prevention of } \mathrm{CV} \text { disease }\end{array}$} \\
\hline \multicolumn{4}{|l|}{ Achieving total cholesterol $<5 \mathrm{mmol} / \mathrm{L}$} \\
\hline \multicolumn{4}{|l|}{$<4 \mathrm{mmol} / \mathrm{L}$} \\
\hline \multicolumn{4}{|l|}{ Achieving LDL cholesterol <3 mmol/L } \\
\hline \multicolumn{4}{|l|}{$<2 \mathrm{mmol} / \mathrm{L}$} \\
\hline \multicolumn{4}{|l|}{ Achieving non-HDL cholesterol $<3$ mmol/L } \\
\hline \multicolumn{4}{|l|}{$<2.5 \mathrm{mmol} / \mathrm{L}$} \\
\hline \multicolumn{4}{|l|}{ Patients on dialysis } \\
\hline \multicolumn{4}{|l|}{$\begin{array}{l}\text { Fasting lipids measured during first } 6 \text { months } \\
\text { of starting dialysis }\end{array}$} \\
\hline \multicolumn{4}{|l|}{$\begin{array}{l}\text { Taking statins for primary or secondary } \\
\text { prevention of } \mathrm{CV} \text { disease }\end{array}$} \\
\hline \multicolumn{4}{|l|}{ Achieving total cholesterol $<5 \mathrm{mmol} / \mathrm{L}$} \\
\hline \multicolumn{4}{|l|}{$<4 \mathrm{mmol} / \mathrm{L}$} \\
\hline \multicolumn{4}{|l|}{ Achieving LDL cholesterol <3 mmol/L } \\
\hline \multicolumn{4}{|l|}{$<2 \mathrm{mmol} / \mathrm{L}$} \\
\hline \multicolumn{4}{|l|}{ Achieving non-HDL cholesterol $<3$ mmol/L } \\
\hline \multicolumn{4}{|l|}{$<2.5 \mathrm{mmol} / \mathrm{L}$} \\
\hline \multicolumn{4}{|l|}{ Renal transplant patients } \\
\hline \multicolumn{4}{|l|}{ Fasting lipids measured annually } \\
\hline \multicolumn{4}{|l|}{$\begin{array}{l}\text { Taking statins for primary or secondary } \\
\text { prevention of } \mathrm{CV} \text { disease }\end{array}$} \\
\hline \multicolumn{4}{|l|}{ Achieving total cholesterol $<5 \mathrm{mmo} / \mathrm{L}$} \\
\hline \multicolumn{4}{|l|}{$<4 \mathrm{mmol} / \mathrm{L}$} \\
\hline \multicolumn{4}{|l|}{ Achieving LDL cholesterol <3 mmol/L } \\
\hline \multicolumn{4}{|l|}{$<2 \mathrm{mmol} / \mathrm{L}$} \\
\hline \multicolumn{4}{|l|}{ Achieving non-HDL cholesterol $<3 \mathrm{mmol} / \mathrm{L}$} \\
\hline$<2.5 \mathrm{mmol} / \mathrm{L}$ & & & \\
\hline
\end{tabular}

\section{Is there more?}

The full guidance also considers issues for further research as well as areas of therapeutic uncertainty. *

Acknowledgements The writing group of the Association of British Clinical Diabetologists ( $A B C D$ ) and the Renal Association (RA) Diabetes Mellitus and Chronic Kidney Disease guideline writing group have reviewed this summary of the guidelines.

Conflict of interest Peter Winocour has received honoraria for delivering educational meetings and/or attending advisory boards for AstraZeneca and MSD

\section{Funding None}

The full guideline and links to this abridged guideline will be available via the $A B C D$ (www.diabetologists-abcd.org.uk) and Renal Association (www.renal.org) websites.

\section{Key messages}

- Diabetic nephropathy and chronic kidney disease increase cardiovascular risk

- Lipid management, sensitive to renal status, reduces cardiovascular risk

\section{References}

* Mark PB, Winocour P. ABCD-Renal Association Clinical Practice Guidelines for management of lipids in adults with diabetes mellitus and nephropathy and/or chronic kidney disease. 2017. www. diabetologistsabcd.org.uk and www.renal.org

1. Mactier R. Renal Association Clinical Practice Guideline development policy manual. Nephron Clin Pract 2011;118(Suppl 1):c13-25. http:dx.doi.org/10.1159/000328059

2. Uhlig K, Macleod A, Craig J, et al. Grading evidence and recommendations for clinical practice guidelines in nephrology. A position statement from Kidney Disease: Improving Global Outcomes (KDIGO). Kidney Int 2006; 70:2058-65. http:dx.doi.org/10.1038/sj.ki.5001875

3. Barnett KN, Ogston SA, McMurdo ME, Morris Ad, Evans JM. A 12-year follow-up study of all-cause and cardiovascular mortality among 10,532 people newly diagnosed with type 2 diabetes in Tayside, Scotland. Diabet Med 2010;27:1124-9.

http:dx.doi.org/10.1111/j.1464-5491.2010.03075.x

4. JBS3 Board. Joint British Societies' consensus recommendations for the prevention of cardiovascular disease (JBS3). Heart 2014;100(Suppl 2): ii1-ii67. http:dx.doi.org/10.1136/heartjnl-2014-305693

5. Deckert T, Poulsen JE, Larsen M. Prognosis of diabetics with diabetes onset before the age of thirty-one. II. Factors influencing the prognosis. Diabetologia 1978;14:371-7.

6. Emerging Risk Factors Collaboration, Sarwar N, Gao P, Seshasai SR, et al Diabetes mellitus, fasting blood glucose concentration, and risk of vascular disease: a collaborative meta-analysis of 102 prospective studies. Lancet 2010;375:2215-22. http:dx.doi.org/10.1016/S0140-6736(10)60484-9.

7. Emerging Risk Factors Collaboration, Seshasai SR, Kaptoge S, Thompson $A$, et al. Diabetes mellitus, fasting glucose, and risk of cause-specific death. N Engl J Med 2011;364:829-41. http:dx.doi.org/10.1056/NEJMoa1008862

8. Lewis S, MacLeod M, McKnight J, et al. Predicting vascular risk in type 1 diabetes: stratification in a hospital based population in Scotland. Diabet Med 2005;22:164-71.

9. Livingstone SJ, Looker HC, Hothersall EJ, et al. Risk of cardiovascular disease and total mortality in adults with type 1 diabetes: Scottish registry linkage study. PLoS Med 2012;9:e1001321. http:dx.doi.org/10.1371/journal.pmed. 1001321

10. Preiss D, Sattar N, McMurray JJ. A systematic review of event rates in clinical trials in diabetes mellitus: the importance of quantifying baseline cardiovascular disease history and proteinuria and implications for clinical trial design. Am Heart J 2011;161:210-19e1. http:dx.doi.org/10.1016/j.ahj.2010.10.019

11. Soedamah-Muthu SS, Fuller JH, Mulnier HE, Raleigh VS, Lawrenson RA, Colhoun HM. High risk of cardiovascular disease in patients with type 1 diabetes in the U.K.: a cohort study using the general practice research database. Diabetes Care 2006;29:798-804

12. Torffvit $\mathrm{O}$, Lovestam-Adrian $\mathrm{M}$, Agardh E, Agardh CD. Nephropathy, but not retinopathy, is associated with the development of heart disease in type 1 diabetes: a 12-year observation study of 462 patients. Diabet Med 2005;22:723-9

13. Tuomilehto J, Borch-Johnsen K, Molarius A, et al. Incidence of cardiovas- 
cular disease in type 1 (insulin-dependent) diabetic subjects with and without diabetic nephropathy in Finland. Diabetologia 1998;41:784-90.

14. Wannamethee SG, Shaper AG, Whincup PH, Lennon L, Sattar N. Impact of diabetes on cardiovascular disease risk and all-cause mortality in older men: influence of age at onset, diabetes duration, and established and novel risk factors. Arch Intern Med 2011;171:404-10. http:dx.doi.org/10.1001/archinternmed.2011.2

15. Groop PH, Thomas MC, Moran JL, et al. The presence and severity of chronic kidney disease predicts all-cause mortality in type 1 diabetes. Diabetes 2009;58:1651-8. http:dx.doi.org/10.2337/db08-1543

16. Chronic Kidney Disease Prognosis Consortium, Matsushita K, van der Velde $\mathrm{M}$, Astor BC, et al. Association of estimated glomerular filtration rate and albuminuria with all-cause and cardiovascular mortality in general population cohorts: a collaborative meta-analysis. Lancet 2010;375:2073-81. http:dx.doi.org/10.1016/S0140-6736(10)60674-5

17. Tonelli M, Muntner P, Lloyd A, et al. Association between LDL-C and risk of myocardial infarction in CKD. J Am Soc Nephrol 2013;24:979-86. http:dx.doi.org/10.1681/ASN.2012080870

18. Summary of revisions to the 2014 Clinical Practice Recommendations. Diabetes Care 2014;37(Suppl 1):S4. http:dx.doi.org/10.2337/dc14-S004

19. Rydén L, Grant PJ, Anker SD, et al. ESC quidelines on diabetes, pre-diabetes, and cardiovascular diseases developed in collaboration with the EASD: the Task Force on diabetes, pre-diabetes, and cardiovascular diseases of the European Society of Cardiology (ESC) and developed in collaboration with the European Association for the Study of Diabetes (EASD). Eur Heart J 2013;34:3035-87. http:dx.doi.org/10.1093/eurheart//eht108

20. Tonelli M, Wanner C, Kidney Disease: Improving Global Outcomes Lipid Guideline Development Work Group Members. Lipid management in chronic kidney disease: synopsis of the Kidney Disease: Improving Global Outcomes 2013 clinical practice guideline. Ann Intern Med 2014;160:182. http:dx.doi.org/10.7326/M13-2453

21. Pambianco G, Costacou T, Ellis D, Becker DJ, Klein R, Orchard TJ. The 30year natural history of type 1 diabetes complications: the Pittsburgh Epidemiology of Diabetes Complications Study experience. Diabetes 2006;55:1463-9.

22. Tolonen N, Forsblom C, Makinen VP, et al. Different lipid variables predict incident coronary artery disease in patients with type 1 diabetes with or without diabetic nephropathy: the FinnDiane study. Diabetes Care 2014;37:2374-82. http:dx.doi.org/10.2337/dc13-2873.

23. National Institute for Health and Care Excellence (NICE). Lipid modification: cardiovascular risk assessment and the modification of blood lipids for the primary and secondary prevention of cardiovascular disease. NICE guideline CG181, 2014. https://www.nice.org.uk/guidance/cg181

24. Maftei $\mathrm{O}$, Pena AS, Sullivan $\mathrm{T}$, et al. Early atherosclerosis relates to urinary albumin excretion and cardiovascular risk factors in adolescents with type 1 diabetes: Adolescent type 1 Diabetes cardio-renal Intervention Trial (AdDIT). Diabetes Care 2014;37:3069-75. http://dx.doi.org/10.2337/dc14-0700

25. Collins R, Armitage J, Parish S, et al. MRC/BHF Heart Protection Study of cholesterol-lowering with simvastatin in 5963 people with diabetes: a randomised placebo-controlled trial. Lancet 2003:361:2005-16.

26. Cholesterol Treatment Trialists' Collaborators, Kearney PM, Blackwell L, Collins R, et al. Efficacy of cholesterol-lowering therapy in 18,686 people with diabetes in 14 randomised trials of statins: a meta-analysis. Lancet 2008:371:117-25. http:dx.doi.org/10.1016/S0140-6736(08)60104-X

27. Sniderman AD, Lamarche B, Tilley J, Seccombe D, Frohlich J. Hypertriglyceridemic hyperapoB in type 2 diabetes. Diabetes Care 2002;25:579-82.

28. Taskinen MR, Barter PJ, Ehnholm C, et al. Ability of traditional lipid ratios and apolipoprotein ratios to predict cardiovascular risk in people with type 2 diabetes. Diabetologia 2010;53:1846-55.

http:dx.doi.org/10.1007/s00125-010-1806-9

29. Winocour PH, Durrington PN, Ishola M, et al. Lipoprotein abnormalities in insulin-dependent diabetes mellitus. Lancet 1986;1:1176-8.

30. Chaturvedi N, Fuller JH, Taskinen MR, et al. Differing associations of lipid and lipoprotein disturbances with the macrovascular and microvascular complications of type 1 diabetes. Diabetes Care 2001;24:2071-7.

31. Groop PH, Elliott T, Ekstrand A, et al. Multiple lipoprotein abnormalities in type I diabetic patients with renal disease. Diabetes 1996;45:974-9.

32. Kwan BC, Kronenberg F, Beddhu S, Cheung AK. Lipoprotein metabolism and lipid management in chronic kidney disease. J Am Soc Nephrol 2007;18:1246-61.
33. Niskanen L, Uusitupa M, Sarlund $H$, et al. Microalbuminuria predicts the development of serum lipoprotein abnormalities favouring atherogenesis in newly diagnosed type 2 (non-insulin-dependent) diabetic patients. Diabetologia 1990;33:237-43.

34. Sacks FM, Hermans MP, Fioretto $P$, et al. Association between plasma triglycerides and high-density lipoprotein cholesterol and microvascular kidney disease and retinopathy in type 2 diabetes mellitus: a global casecontrol study in 13 countries. Circulation 2014;129:999-1008. http:dx.doi.org/ 10.1161/CIRCULATIONAHA.113.002529

35. Sibley SD, Hokanson JE, Steffes MW, et al. Increased small dense LDL and intermediate-density lipoprotein with albuminuria in type 1 diabetes. Diabetes Care 1999;22:1165-70.

36. Tolonen N, Forsblom C, Thorn L, et al. Relationship between lipid profiles and kidney function in patients with type 1 diabetes. Diabetologia 2008:51:12-20

37. Winocour PH, Durrington PN, Bhatnagar D, et al. Influence of early diabetic nephropathy on very low density lipoprotein (VLDL), intermediate density lipoprotein (IDL), and low density lipoprotein (LDL) composition. Atherosclerosis 1991:89:49-57.

38. Hovind P, Rossing P, Tarnow L, et al. Progression of diabetic nephropathy Kidney Int 2001;:59:702-09.

39. Raile K, Galler A, Hofer S, et al. Diabetic nephropathy in 27,805 children, adolescents, and adults with type 1 diabetes: effect of diabetes duration, A1C, hypertension, dyslipidemia, diabetes onset, and sex. Diabetes Care 2007:30:2523-8.

40. Thorn LM, Forsblom C, Wadén J, et al. Metabolic syndrome as a risk factor for cardiovascular disease, mortality, and progression of diabetic nephropathy in type 1 diabetes. Diabetes Care 2009;32:950-2. http:dx.doi.org/10.2337/dc08-2022

41. Tolonen N, Forsblom C, Thorn L, et al. Lipid abnormalities predict progression of renal disease in patients with type 1 diabetes. Diabetologia 2009:52:2522-30. http:dx.doi.org/10.1007/s00125-009-1541-2

42. Boekholdt SM, Arsenault BJ, Mora S, et al. Association of LDL cholesterol, non-HDL cholesterol, and apolipoprotein B levels with risk of cardiovascular events among patients treated with statins: a meta-analysis. JAMA 2012;307:1302-09. http:dx.doi.org/10.1001/jama.2012.366

43. Lehto S, Ronnemaa T, Pyorala K, et al. Poor glycemic control predicts coronary heart disease events in patients with type 1 diabetes without nephropathy. Arterioscler Thromb Vasc Biol 1999;19:1014-19.

44. Orchard TJ, Costacou T, Kretowski A, Nesto RW. Type 1 diabetes and coronary artery disease. Diabetes Care 2006;29:2528-38

45. Soedamah-Muthu SS, Chaturvedi N, Toeller M, et al. Risk factors for coronary heart disease in type 1 diabetic patients in Europe: the EURODIAB Prospective Complications Study. Diabetes Care 2004;27:530-7.

46. Soedamah-Muthu SS, Chaturvedi N, Witte DR, et al. Relationship between risk factors and mortality in type 1 diabetic patients in Europe: the EURODIAB Prospective Complications Study (PCS). Diabetes Care 2008; 31:1360-6. http:dx.doi.org/10.2337/dc08-0107

47. Nordwall $M$, Bojestig $M$, Arnqvist $\mathrm{HJ}$, et al. Declining incidence of severe retinopathy and persisting decrease of nephropathy in an unselected population of type 1 diabetes: the Linkoping Diabetes Complications Study. Diabetologia 2004;47:1266-72.

48. Dahl-Jorgensen K, Larsen JR, Hanssen KF. Atherosclerosis in childhood and adolescent type 1 diabetes: early disease, early treatment? Diabetologia 2005:48:1445-53.

49. Krolewski AS, Niewczas MA, Skupien J, et al. Early progressive renal decline precedes the onset of microalbuminuria and its progression to macroalbuminuria. Diabetes Care 2014:37:226-34. http:dx.doi.org/10.2337/dc13-0985

50. Stewart MW, Laker MF, Dyer RG, et al. Lipoprotein compositional abnormalities and insulin resistance in type II diabetic patients with mild hyperlipidemia. Arterioscler Thromb 1993;13:1046-52.

51. Niskanen L, Turpeinen A, Penttila I, et al. Hyperglycemia and compositional lipoprotein abnormalities as predictors of cardiovascular mortality in type 2 diabetes: a 15-year follow-up from the time of diagnosis. Diabetes Care 1998;21:1861-9.

52. Haffner SM, Lehto S, Ronnemaa T, et al. Mortality from coronary heart disease in subjects with type 2 diabetes and in nondiabetic subjects with and without prior myocardial infarction. N Engl J Med 1998;339:229-34.

53. Fox CS, Matsushita K, Woodward M, et al. Associations of kidney disease 
measures with mortality and end-stage renal disease in individuals with and without diabetes: a meta-analysis. Lancet 2012;380:1662-73. http:dx.doi.org/10.1016/S0140-6736(12)61350-6.

54. Tonelli M, Moye L, Sacks FM, et al. Pravastatin for secondary prevention of cardiovascular events in persons with mild chronic renal insufficiency. Ann Intern Med 2003;138:98-104.

55. Tonelli M, Isles C, Curhan GC, et al. Effect of pravastatin on cardiovascular events in people with chronic kidney disease. Circulation 2004;110:155763.

56. Tonelli M, Keech A, Shepherd J, et al. Effect of pravastatin in people with diabetes and chronic kidney disease. J Am Soc Nephrol 2005;16:374854.

57. Shepherd J, Kastelein JJ, Bittner $\mathrm{V}$, et al. Intensive lipid lowering with atorvastatin in patients with coronary heart disease and chronic kidney disease: the TNT (Treating to New Targets) study. J Am Coll Cardio/ 2008;51:144854. 10.1016/j.jacc.2007.11.072

58. Baigent C, Landray MJ, Reith C, et al. The effects of lowering LDL cholesterol with simvastatin plus ezetimibe in patients with chronic kidney disease (Study of Heart and Renal Protection): a randomised placebo-controlled trial. Lancet 2011;377:2181-92. http://dx.doi.org/10.1016/S0140-6736(11)60739-3

59. Colhoun HM, Betteridge DJ, Durrington PN, et al. Effects of atorvastatin on kidney outcomes and cardiovascular disease in patients with diabetes: an analysis from the Collaborative Atorvastatin Diabetes Study (CARDS). Am J Kidney Dis 2009;54:810-19. http:dx.doi.org/10.1053/j.ajkd.2009.03.022

60. Shepherd J, Kastelein JP, Bittner VA, et al. Intensive lipid lowering with atorvastatin in patients with coronary artery disease, diabetes, and chronic kidney disease. Mayo Clin Proc 2008:83:870-9.

61. Cannon $\mathrm{CP}$, Blazing MA, Giugliano RP, et al. Ezetimibe added to statin therapy after acute coronary syndromes. N Engl J Med 2015;372:238797. http:dx.doi.org/10.1056/NEJMoa1410489

62. Law MR, Wald NJ, Rudnicka AR. Quantifying effect of statins on low density lipoprotein cholesterol, ischaemic heart disease, and stroke: systematic review and meta-analysis. BMJ 2003;326:1423.

63. Gaede P, Vedel P, Larsen N, Jensen GV, Parving HH, Pedersen O. Multifactorial intervention and cardiovascular disease in patients with type 2 diabetes. N Engl J Med 2003;348:383-93.

64. Strippoli GF, Navaneethan SD, Johnson DW, et al. Effects of statins in patients with chronic kidney disease: meta-analysis and meta-regression of randomised controlled trials. BMJ 2008:336:645-51. http:dx.doi.org/10.1136/bmj.39472.580984.AE

65. Upadhyay A, Earley A, Lamont JL, Haynes S, Wanner C, Balk EM. Lipidlowering therapy in persons with chronic kidney disease: a systematic review and meta-analysis. Ann Intern Med 2012;157:251-62. http:dx.doi.org/10.7326/0003-4819-157-4-201208210-00005

66. Hou W, Lv J, Perkovic V, et al. Effect of statin therapy on cardiovascular and renal outcomes in patients with chronic kidney disease: a systematic review and meta-analysis. Eur Heart J 2013;34:1807-17. http:dx.doi.org/10.1093/eurheartj/eht065

67. Shepherd J, Kastelein JJ, Bittner $\mathrm{V}$, et al. Effect of intensive lipid lowering with atorvastatin on renal function in patients with coronary heart disease: the Treating to New Targets (TNT) study. Clin J Am Soc Nephrol 2007; 2:1131-9.

68. Rutter MK, Prais HR, Charlton-Menys V, et al. Protection Against Nephropathy in Diabetes with Atorvastatin (PANDA): a randomized double-blind placebo-controlled trial of high- vs. low-dose atorvastatin. Diabet Med 2011:28:100-08. http:dx.doi.org/10.1111/j.1464-5491.2010.03139.x

69. Haynes R, Lewis D, Emberson J, et al. Effects of lowering LDL cholesterol on progression of kidney disease. J Am Soc Nephrol 2014:25:1825-33. http:dx.doi.org/10.1681/ASN.2013090965

70. Ridker PM, MacFadyen J, Cressman M, Glynn RJ. Efficacy of rosuvastatin among men and women with moderate chronic kidney disease and elevated high-sensitivity C-reactive protein: a secondary analysis from the JUPITER (Justification for the Use of Statins in Prevention-an Intervention Trial Evaluating Rosuvastatin) trial. J Am Coll Cardiol 2010;55:1266-73. http:dx.doi.org/10.1016/j.jacc.2010.01.020

71. Kimura S, Inoguchi T, Yokomizo H, et al. Randomized comparison of pitavastatin and pravastatin treatment on the reduction of urinary albumin in patients with type 2 diabetic nephropathy. Diabetes Obes Metab 2012;14:666-9. http:dx.doi.org/10.1111/j.1463-1326.2012.01566.x

72. de Zeeuw D, Anzalone DA, Cain VA, et al. Renal effects of atorvastatin and rosuvastatin in patients with diabetes who have progressive renal disease (PLANET I): a randomised clinical trial. Lancet Diabetes Endocrinol 2015:3:181-90. http:dx.doi.org/10.1016/\$2213-8587(14)70246-3

73. Lai CL, Chou HW, Chan KA, Lai MS. Effects of atorvastatin and rosuvastatin on renal function in patients with type 2 diabetes mellitus. Am J Cardiol 2015;115:619-24. http:dx.doi.org/10.1016/j.amjcard.2014.12.009

74. Wan RK, Mark PB, Jardine AG. The cholesterol paradox is flawed; cholesterol must be lowered in dialysis patients. Semin Dial 2007;20:504-09.

75. Wanner C, Tonelli M, Kidney Disease: Improving Global Outcomes Lipid Guideline Development Work Group Members. KDIGO Clinical Practice Guideline for Lipid Management in CKD: summary of recommendation statements and clinical approach to the patient. Kidney Int 2014;85:13039. http:dx.doi.org/10.1038/ki.2014.31

76. Wanner C, Krane V, März W, et al. Atorvastatin in patients with type 2 diabetes mellitus undergoing hemodialysis. N Engl J Med 2005;353: 238-48.

77. Fellstrom BC, Jardine AG, Schmieder RE, et al. Rosuvastatin and cardiovascular events in patients undergoing hemodialysis. N Engl J Med 2009;360:1395-407. http:dx.doi.org/10.1056/NEJMoa0810177

78. Holdaas $\mathrm{H}$, Holme I, Schmieder RE, et al. Rosuvastatin in diabetic hemodialysis patients. J Am Soc Nephrol 2011;22:1335-41. http:dx.doi.org/10.1681/ASN.2010090987

79. Mason NA, Bailie GR, Satayathum S, et al. HMG-coenzyme a reductase inhibitor use is associated with mortality reduction in hemodialysis patients. Am J Kidney Dis 2005;45:119-26. http://dx.doi.org/10.1053/j.ajkd.2004.09.025

80. Jardine AG, Gaston RS, Fellstrom BC, Holdaas H. Prevention of cardiovascular disease in adult recipients of kidney transplants. Lancet 2011; 378:1419-27. http:dx.doi.org/10.1016/S0140-6736(11)61334-2

81. Miller LW. Cardiovascular toxicities of immunosuppressive agents. Am J Transplant 2002:2:807-18.

82. Riella LV, Gabardi S, Chandraker A. Dyslipidemia and its therapeutic challenges in renal transplantation. Am J Transplant 2012;12:1975-82. http:dx.doi.org/10.1111/j.1600-6143.2012.04084.x

83. Holdaas $\mathrm{H}$, Fellstrom $B$, Jardine $A G$, et al. Effect of fluvastatin on cardiac outcomes in renal transplant recipients: a multicentre, randomised, placebo-controlled trial. Lancet 2003:361:2024-31.

84. Holdaas H, Fellstrom B, Cole E, et al. Long-term cardiac outcomes in renal transplant recipients receiving fluvastatin: the ALERT extension study. Am J Transplant 2005;5:2929-36.

85. Jardine AG, Fellstrom B, Logan JO, et al. Cardiovascular risk and renal transplantation: post hoc analyses of the Assessment of Lescol in Renal Transplantation (ALERT) Study. Am J Kidney Dis 2005:46:529-36.

86. Stirling CM, Isles CG. Rhabdomyolysis due to simvastatin in a transplant patient: Are some statins safer than others? Nephrol Dial Transplant 2001;16:873-4

87. Turk TR, Voropaeva E, Kohnle M, et al. Ezetimibe treatment in hypercholesterolemic kidney transplant patients is safe and effective and reduces the decline of renal allograft function: a pilot study. Nephrol Dial Transplant 2008:23:369-73.

88. Buchanan C, Smith L, Corbett J, Nelson E, Shihab F. A retrospective analysis of ezetimibe treatment in renal transplant recipients. Am J Transplant 2006:6:770-4

89. Stevens KK, Patel RK, Jardine AG. How to identify and manage diabetes mellitus after renal transplantation. J Ren Care 2012:38(Suppl 1):125-37. http:dx.doi.org/10.1111/j.1755-6686.2012.00282.x

90. Dean PG, Kudva YC, Stegall MD. Long-term benefits of pancreas transplantation. Curr Opin Organ Transplant 2008;13:85-90. http:dx.doi.org/10.1097/MOT.0b013e3282f2fd7f

91. Preiss $D$, Tikkanen MJ, Welsh $P$, et al. Lipid-modifying therapies and risk of pancreatitis: a meta-analysis. JAMA 2012;308:804-11. http:dx.doi.org/1001/jama.2012.8439

92. Graham DJ, Staffa JA, Shatin D, et al. Incidence of hospitalized rhabdomyolysis in patients treated with lipid-lowering drugs. JAMA 2004;292: 2585-90

93. Navaneethan SD, Pansini F, Perkovic $V$, et al. HMG CoA reductase inhibitors (statins) for people with chronic kidney disease not requiring dialysis. 
Cochrane Database Syst Rev 2009:CD007784

94. Fellstrom $B$, Holdaas $H$, Jardine $A G$, et al. Effect of rosuvastatin on outcomes in chronic haemodialysis patients: baseline data from the AURORA study. Kidney Blood Press Res 2007;30:314-22.

95. Ridker PM, Danielson E, Fonseca FA, et al. Rosuvastatin to prevent vascular events in men and women with elevated C-reactive protein. N Engl J Med 2008;359:2195-207. http:dx.doi.org/10.1056/NEJMoa0807646

96. Keech A, Simes RJ, Barter P, et al. Effects of long-term fenofibrate therapy on cardiovascular events in 9795 people with type 2 diabetes mellitus (the FIELD study): randomised controlled trial. Lancet 2005;366:1849-61.

97. ACCORD Study Group, Ginsberg HN, Elam MB, Lovato LC, et al. Effects of combination lipid therapy in type 2 diabetes mellitus. N Engl J Med 2010;362:1563-74. http:dx.doi.org/10.1056/NEJMoa1001282

98. Davis TM, Ting R, Best JD, et al. Effects of fenofibrate on renal function in patients with type 2 diabetes mellitus: the Fenofibrate Intervention and Event Lowering in Diabetes (FIELD) Study. Diabetologia 2011;54:280-90. http:dx.doi.org/10.1007/s00125-010-1951-1

99. Mychaleckyj JC, Craven T, Nayak U, et al. Reversibility of fenofibrate therapy-induced renal function impairment in ACCORD type 2 diabetic participants. Diabetes Care 2012;35:1008-14. http:dx.doi.org/10.2337/dc11-1811

100. Ansquer JC, Foucher C, Rattier $S$, et al. Fenofibrate reduces progression to microalbuminuria over 3 years in a placebo-controlled study in type 2 diabetes: results from the Diabetes Atherosclerosis Intervention Study (DAIS). Am J Kidney Dis 2005;45:485-93.

101. Bonds DE, Craven TE, Buse J, et al. Fenofibrate-associated changes in renal function and relationship to clinical outcomes among individuals with type 2 diabetes: the Action to Control Cardiovascular Risk in Diabetes (ACCORD) experience. Diabetologia 2012;55:1641-50. http:dx.doi.org/10.1007/s00125-012-2524-2

102. Ting RD, Keech AC, Drury PL, et al. Benefits and safety of long-term fenofibrate therapy in people with type 2 diabetes and renal impairment: the FIELD Study. Diabetes Care 2012;35:218-25. http:dx.doi.org/10.2337/dc11-1109

103. Weinstein DL, Williams LA, Carlson DM, et al. A randomized, double-blind study of fenofibric acid plus rosuvastatin compared with rosuvastatin alone in stage 3 chronic kidney disease. Clin Ther 2013;35:1186-98. http:dx.doi.org/10.1016/j.clinthera.2013.06.013

104. Jun M, Foote C, Lv J, et al. Effects of fibrates on cardiovascular outcomes: a systematic review and meta-analysis. Lancet 2010;375:1875-84. http:dx.doi.org/10.1016/S0140-6736(10)60656-3

105. Jun $M$, Zhu B, Tonelli $M$, et al. Effects of fibrates in kidney disease: a systematic review and meta-analysis. J Am Coll Cardiol 2012;60:2061-71. http:dx.doi.org/10.1016/j.jacc.2012.07.049

106. Zhao YY, Weir MA, Manno M, et al. New fibrate use and acute renal outcomes in elderly adults: a population-based study. Ann Intern Med 2012;156:560-9.

http:dx.doi.org/10.7326/0003-4819-156-8-201204170-00003
107. Choi HD, Shin WG. Safety and efficacy of statin treatment alone and in combination with fibrates in patients with dyslipidemia: a meta-analysis. Curr Med Res Opin 2014;30:1-10.

http:dx.doi.org/10.1185/03007995.2013.842165

108. Geng Q, Ren J, Chen H, Lee C, Liang W. Adverse events of statin-fenofibric acid versus statin monotherapy: a meta-analysis of randomized controlled trials. Curr Med Res Opin 2013;29:181-8. http:dx.doi.org/10.1185/03007995.2013.766592

109. Catapano AL. New insights on ezetimibe. Introduction. Atheroscler Suppl 2015;17:1. http:dx.doi.org/10.1016/S1567-5688(15)50001-9

110. Leiter LA, Betteridge DJ, Farnier $M$, et al. Lipid-altering efficacy and safety profile of combination therapy with ezetimibe/statin vs. statin monotherapy in patients with and without diabetes: an analysis of pooled data from 27 clinical trials. Diabetes Obes Metab 2011;13:615-28. http:dx.doi.org/10.1111/j.1463-1326.2011.01383.x

111. Altschul R, Hoffer A, Stephen JD. Influence of nicotinic acid on serum cholesterol in man. Arch Biochem Biophys 1955;54:558-9.

112. Grundy SM, Vega GL, McGovern ME, et al. Efficacy, safety, and tolerability of once-daily niacin for the treatment of dyslipidemia associated with type 2 diabetes: results of the assessment of diabetes control and evaluation of the efficacy of niaspan trial. Arch Intern Med 2002;162:1568-76.

113. Ix JH, Ganjoo P, Tipping D, Tershakovec AM, Bostom AG. Sustained hypophosphatemic effect of once-daily niacin/laropiprant in dyslipidemic CKD stage 3 patients. Am J Kidney Dis 2011;57:963-5. http:dx.doi.org/10.1053/j.ajkd.2011.03.010

114. Reiche I, Westphal S, Martens-Lobenhoffer J, et al. Pharmacokinetics and dose recommendations of Niaspan $\circledast$ in chronic kidney disease and dialysis patients. Nephrol Dial Transplant 2011;26:276-82. http:dx.doi.org/10.1093/ndt/gfq344

115. He YM, Feng L, Huo DM, Yang ZH, Liao YH. Benefits and harm of niacin and its analog for renal dialysis patients: a systematic review and metaanalysis. Int Urol Nephrol 2014;46:433-42. http:dx.doi.org/10.1007/s11255-013-0559-z

116. AIM-HIGH Investigators, Boden WE, Probstfield JL, Anderson T, et al. Niacin in patients with low HDL cholesterol levels receiving intensive statin therapy. N Engl J Med 2011;365:2255-67. http:dx.doi.org/10.1056/NEJMoa1107579

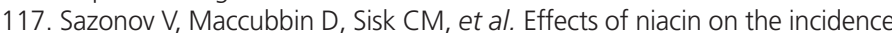
of new onset diabetes and cardiovascular events in patients with normoglycaemia and impaired fasting glucose. Int J Clin Pract 2013;67:297-302. http:dx.doi.org/10.1111/ijcp.12089

118. HPS2-THRIVE Collaborative Group, Landray MJ, Haynes R, Hopewell JC, et al. Effects of extended-release niacin with laropiprant in high-risk patients. N Engl J Med 2014;371:203-12. http:dx.doi.org/10.1056/NEJMoa1300955

119. Landray MJ, Haynes R, Armitage J. Niacin for reduction of cardiovascular risk. N Engl J Med 2014;371:1943-4. http:dx.doi.org/10.1056/NEJMc1411240 